\title{
Analysis of yield traits, oil content and protein concentration in canola (Brassica napus L.) in relation to various nitrogen and seed rates
}

\author{
Shah Nawaz Khan ${ }^{1}$, Zahid Hussain ${ }^{1}$, Wajid Ali Shah ${ }^{1}$, Subhan Uddin², \\ Manzoor Ahmad ${ }^{1}$, Roohul Amin ${ }^{1}$, Muhammad Ishaq ${ }^{1 *}$, Aamir Khan ${ }^{1}$, \\ Muhammad Wisal ${ }^{1}$, Sefat Ullah ${ }^{1}$ and Murad Ali ${ }^{1}$ \\ 1. Department of Agriculture - Agronomy, Bacha Khan University, Charsadda-Pakistan \\ 2. Department of Agricultural Mechanization, The University of Agriculture Peshawar-Pakistan \\ *Corresponding author's email: ishaqagronomist@gmail.com
}

Citation

Shah Nawaz Khan, Zahid Hussain, Wajid Ali Shah, Subhan Uddin, Manzoor Ahmad, Roohul Amin, Muhammad Ishaq, Aamir Khan, Muhammad Wisal, Sefat Ullah and Murad Ali. Analysis of yield traits, oil content and protein concentration in canola (Brassica napus L.) in relation to various nitrogen and seed rates. Pure and Applied Biology. Vol. 9, Issue 1, pp112-120. http://dx.doi.org/10.19045/bspab.2020.90014

Received: $26 / 06 / 2019$

Revised: $28 / 08 / 2019$

Accepted: 05/09/2019

Online First: 16/09/2019

\section{Abstract}

Nitrogen plays an important role in protein formation, cell improvement, protoplasm and other photosynthetic activities. Therefore, a field study was conducted at Bacha Khan Agricultural Research Farm, Bacha Khan University, Charsadda, during 2015-2016. The experiment was laid down according to Randomized Complete Block design (RCBD) having three replications with plot size of $1.5 \mathrm{~m} \mathrm{x} 4 \mathrm{~m}$. Two factors were studied, i.e. Nitrogen levels $\left(0,50,75 \& 100 \mathrm{~kg} \mathrm{ha}^{-1}\right)$ and Seed rates $\left(3,6\right.$ and $\left.9 \mathrm{~kg} \mathrm{ha}^{-1}\right)$. Seed rates resulted in maximum emergence $\left(55 \mathrm{~m}^{-2}\right)$, plant height $(147 \mathrm{~cm})$, thousand grains weight $(3.4 \mathrm{~g})$ and grain yield (2026 kg ha-1) were recorded with seed rate of $9 \mathrm{~kg} \mathrm{ha}^{-1}$ while minimum days to maturity (155), maximum oil content (45\%), Absolute growth rate (AGR) $\left(7.4 \mathrm{~g} \mathrm{~m}^{-2} \mathrm{day}^{-1}\right)$, grain nitrogen content $(2.6 \%)$ and straw nitrogen content $(1.5 \%)$ were recorded with the seed rate of 3 followed by $6 \mathrm{~kg} \mathrm{ha}^{-1}$. Except emergence, nitrogen performed better and maximum plant height $(147 \mathrm{~cm}), 1000$ grains weight $(3.5$ $\mathrm{g}$ ), grain yield (2211 $\left.\mathrm{kg} \mathrm{ha}^{-1}\right)$, Absolute growth rate (AGR) $\left(10.3 \mathrm{~g} \mathrm{~m}^{-2} \mathrm{day}^{-1}\right)$, Nitrogen content in grain (2.7 $\%)$ and nitrogen content in straw (1.6\%) were achieved with $100 \mathrm{~kg} \mathrm{~N} \mathrm{ha}^{-1}$ while minimum days to maturity (155) and grain oil content (44\%) were obtained with $50 \mathrm{~kg} \mathrm{~N} \mathrm{ha}^{-1}$. Grain yield and oil content of canola increased with seed rate $6 \mathrm{~kg}$ followed by $9 \mathrm{~kg} \mathrm{ha}^{-1}$ while $100 \& 50 \mathrm{~kg} \mathrm{~N} \mathrm{ha}^{-1}$ enhanced grain yield \& oil content.

Keywords: Brassica napus L; Canola; Nitrogen levels; Oil content; Protein content; Seed rates

\section{Introduction}

Canola (Brassica napus L.) is from family Brassicaceae and is used as a vegetable oil in cooking and also as animal feed. It's the world $3^{\text {rd }}$ biggest vegetable oil after palm-oil and soybean [1]. In Pakistan, canola is grown on both irrigated and rainfed area as oil seed crop. [2] While it is grown for fodder purpose as well as serves as a source of edible oil. Edible oil is one of the basic and major requirements of our daily diet. Pakistan is encountered with a deficiency of edible oil 
because of its high consumption about 2.325 million tons, while only 0.606 million tones met through country production while the rest is imported every year. Canola is grown to approx. 217 thousand hectare area with 192-thousand-ton output with an average yield of $\left(886 \mathrm{~kg} \mathrm{ha}^{-1)}\right.$. Whereas in Khyber Pakhtunkhwa (KPK), it occupied 14.3 thousand hectare of area with production of 6.7 thousand tons with an average production of $469 \mathrm{~kg} \mathrm{ha}^{-1}[3,4]$.

Nitrogen plays an important role in increasing crop output. Nitrogen is a basic constituent of protein formation, cell improvement, protoplasm and other photosynthetic activates [5]. If it compares to other cereals, canola requires the most amount of nutrients and nitrogen. Many studies showed that growth and yield of canola could be improved significantly by increasing the dose of nitrogen [6]. But the use of excess nitrogen application can reduce or negatively affect grain yield and quality [7]. More nitrogen applied or improper application can increase nitrogen ratio in grains, which decrease the amount of oil. Increasing nitrogen chemicals and plant population increases grain yield and more yield per hectare attained by the nitrogen application of $225 \mathrm{~kg} \mathrm{ha}^{-1}$ and seeds up-to 90plants per meter $[8,9] .110$ plants in onemeter square is optimized and enhanced yield parameters [10]. Canola grain yield increased with increasing plant population and nitrogen levels [11] because nitrogen is a part of chlorophyll and green pigments in the plant which is a part of its body [12]. Increasing the rate of nitrogen fertilizer and plants per meter square increased and boost grain yield in canola [13]. It confirms from different researches that nitrogen fertilizer increased seed yield of canola and also increased the capacity of oil $[14,15]$.

Heavy winter rains damages plant density and many reports confirmed that reduction in plant population in canola reduced grain yield significantly [16]. High plant population is susceptible to lodging and other risk in the form of disease and low yield [17]. Optimum seed rates and plant density ensure crop competition and control weeds [18]. It's proven that Plant-populations decreased from 80 to 40 plants $\mathrm{m}^{-2}$ can produce more seed yield [19]. Seed rate of $32 \mathrm{~m}^{2}$ to 65 seeds $\mathrm{m}^{-2}$ produced good and significant oil content production [20]. Seed rate is considered important factor to optimize plant density [21]. Seed rates enhance and positively influence the yield and yield contributing characters of canola [22].

\section{Materials and methods}

A field study of various nitrogen and seed rates on canola was conducted at Bacha Khan Agricultural Research Farm (BARF), Bacha Khan University, Charsadda during 20152016. The purpose of this trail was to evaluate yield traits, oil content and protein concentration in grains and straw. The experiment was done according to Randomized Complete Block (RCB) Design having three replications with plot size of $1.5 \mathrm{~m} \times 4 \mathrm{~m}$. Two factors were studied, i.e. nitrogen levels $\left(0,50,75 \& 100 \mathrm{~kg} \mathrm{ha}^{-1}\right)$ and seed rates $\left(3,6\right.$ and $\left.9 \mathrm{~kg} \mathrm{ha}^{-1}\right)$. Nitrogen was applied to the field in two equal split doses. Half dose of nitrogen was added to the field during seed sowing time and the other half was applied at first irrigation. Agronomic, physiological and lab data was recorded during the experiment.

\section{Results and discussion Emergence $\mathbf{~ m}^{-2}$}

Emergence of canola varied by seed rates while the application of nitrogen had no clear influence on emergence $\mathrm{m}^{-2}$ as shown in (Table 1). Emergence $\mathrm{m}^{-2}$ was considerably increased by increasing seed rate and more emergences (51.1 seedlings) were noted with $9 \mathrm{~kg}$ seed rate ha-1 as compared to $3 \mathrm{~kg} \mathrm{ha}^{-1}$. Similar result was reported by [22] who reported that increasing seed rate increased emergence. Among N application non- 
significant effect of nitrogen was found, as seedling consumes less nutrients. Similar result was also reported by [23].

\section{Days to maturity}

Table-1 showed variation in days to maturity by various levels of nitrogen, seed rates and interaction $\mathrm{N} \times \mathrm{SR}$ in canola. More days (159) were taken in maturity stage when 100 $\mathrm{kg} \mathrm{N} \mathrm{ha}^{-1}$ was applied as match to control plots. Increasing the levels of nitrogen delayed the maturity stage of the canola crop due to extension in vegetative production. Similar variation was noted by [24] that increase levels of nitrogen treatments can delay the vegetative stage of crop and increase the vegetative growth. Between different seed rates, $9 \mathrm{~kg}$ seed ha ${ }^{-1}$ took (158 days) in maturity stage, while minimum of (155 days) to maturity were taken with $3 \mathrm{~kg}$ seed rate $\mathrm{ha}^{-1}$. Same results were reported by
[25]. In case of interaction, minimum days were noted with the sole treatments of $50 \mathrm{~kg}$ $\mathrm{N}$ and $3 \mathrm{~kg}$ seed rate ha ${ }^{-1}$ as shown in (Figure 1)

\section{Plant height (cm)}

Significant variation of nitrogen and seed rate were noted for plant height while interaction $\mathrm{N} x \mathrm{SR}$ had no effect as reported in (Table 1). Plots treated with the sole treatment of Nitrogen@100 kg ha ${ }^{-1}$ resulted $(147 \mathrm{~cm})$ taller plants as compared to control. Similar result was observed by $[26,27]$. Among seed rate treatments, $(140 \mathrm{~cm})$ taller plant was observed when $9 \mathrm{~kg}$ seed rate $\mathrm{ha}^{-1}$ as compared to 3 and $6 \mathrm{~kg}$ seed rate $\mathrm{ha}^{-1}$. Increasing in height of plant was observed with increasing seed rate may be due to competitions of plant for environmental factors [28].

Table 1. Represent data on emergence $\mathrm{m}^{-2}$, days to maturity, plant height $(\mathrm{cm})$, of canola as influenced by different nitrogen levels and seeding rates

\begin{tabular}{|c|c|c|c|}
\hline Treatments & Emergence $\mathbf{m}^{-2}$ & Days to maturity & Plant height $(\mathrm{cm})$ \\
\hline Nitrogen $\left(\mathrm{kg} \mathrm{ha}^{-1}\right)$ & cintergence in & & \\
\hline 0 & $47.1 \mathrm{a}$ & $154 \mathrm{c}$ & $131 d$ \\
\hline 50 & $44.8 \mathrm{c}$ & $155 \mathrm{c}$ & $135 \mathrm{c}$ \\
\hline 75 & $46.7 \mathrm{~b}$ & $157 \mathrm{~b}$ & $139 \mathrm{~b}$ \\
\hline 100 & $45.2 \mathrm{c}$ & $159 a$ & $147 \mathrm{a}$ \\
\hline LSD Value & - & 1.11 & 1.17 \\
\hline \multicolumn{4}{|l|}{ Seed rates $\left(\mathrm{kg} \mathrm{ha}^{-1}\right)$} \\
\hline 3 & $33.6 \mathrm{~b}$ & $155 \mathrm{c}$ & $136 \mathrm{c}$ \\
\hline 6 & $49 a$ & $157 \mathrm{~b}$ & $138 b$ \\
\hline 9 & $55.1 \mathrm{a}$ & $158 \mathrm{a}$ & $140 \mathrm{a}$ \\
\hline LSD Value & 6.55 & 0.96 & 1.97 \\
\hline LSD Value for interaction & - & 1.92 & - \\
\hline $\mathbf{S} \times \mathbf{N}$ & Ns & $* *$ & Ns \\
\hline
\end{tabular}

Means with letters differ significantly according to Least-Significant- Difference (LSD) test $(\mathrm{P}<0.05)$, ns stands for non-significant difference and* at $\mathrm{P}<0.05$ level, respectively 


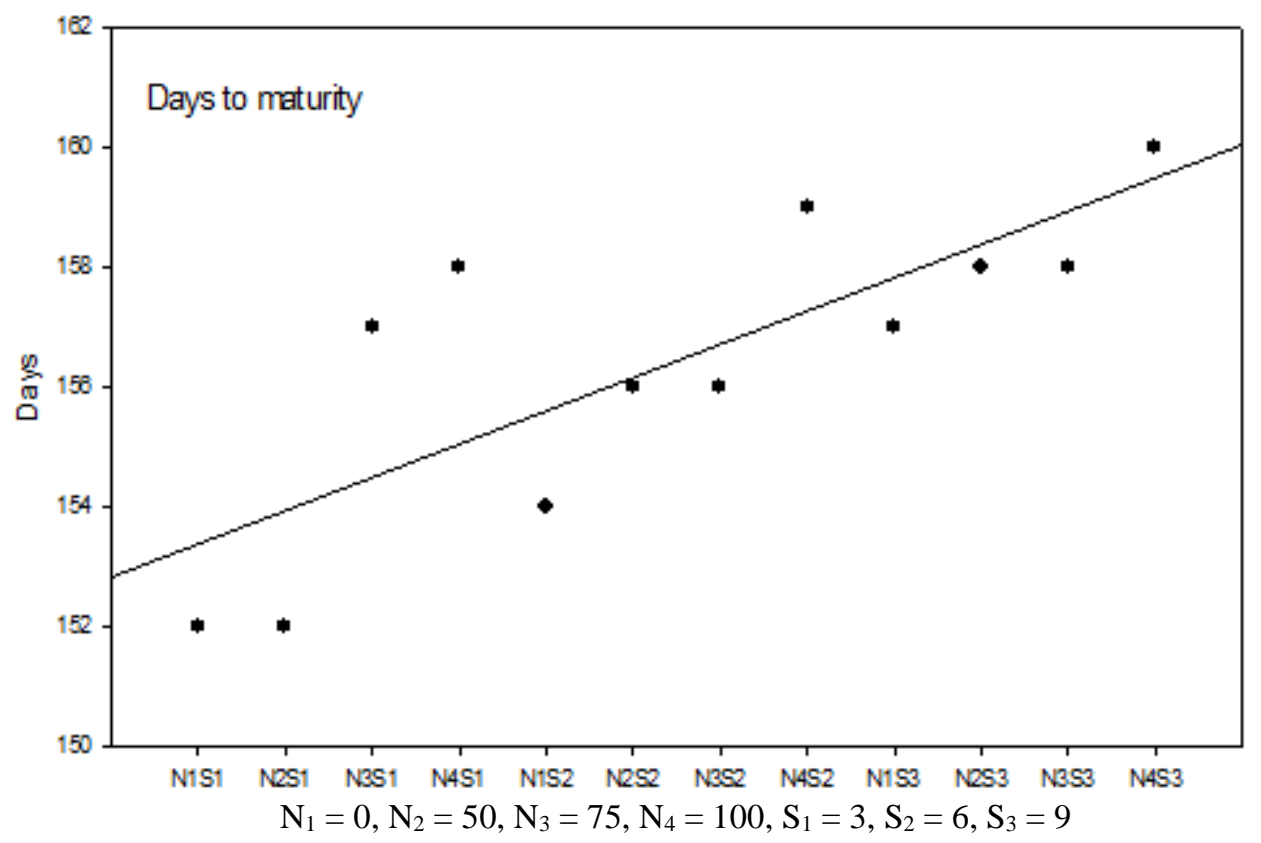

Figure 1. Days to maturity of canola as affected by interaction of different nitrogen levels and seed rates

\section{Thousand grains weight (g)}

1000 grains weight of canola was influenced significantly by various seed rates, nitrogen and as well as interaction $\mathrm{N} x \mathrm{SR}$ as presented in (Table 2). Maximum 1000 grains weight $(3.5 \mathrm{~g})$ was noted in plot treated with@100 $\mathrm{kg} \mathrm{N} \mathrm{ha-1}$ as compared to others nitrogen treatments. The result is in line with the finding of [28] that nitrogen can increase and enhance 1000 grains weight. Among seed rate application, maximum 1000 grains weight $(3.4 \mathrm{~g})$ was recorded with $9 \mathrm{~kg}$ seed rate $\mathrm{ha}^{-1}$ and minimum (3.2 g) was observed with $3 \mathrm{~kg}$ seed rate $\mathrm{ha}^{-1}$. [29]. In case of combinations, heaviest 1000 grains weight was observed when the combine treatments of $75 \mathrm{~kg}$ nitrogen, $9 \mathrm{~kg}$ seed rate $\mathrm{ha}^{-1}$ were used as shown in (Figure 2)

\section{Grain yield (kg ha-1)}

Nitrogen rates and seed rates had significantly impacted grain yield while interaction $\mathrm{N} x \mathrm{SR}$ had no effect as reported in (Table 2). Maximum grain yield $(2211 \mathrm{~kg}$ $\mathrm{ha}^{-1}$ ) was produced with nitrogen @ $100 \mathrm{~kg}$ $\mathrm{ha}^{-1}$, while control plot recorded $\left(1518 \mathrm{~kg} \mathrm{ha}^{-}\right.$ $\left.{ }^{1}\right)$ grain yield. Between seed rate treatments, more grain yield (2026 kg ha-1) was attained with $9 \mathrm{~kg}$ seed rate $\mathrm{ha}^{-1}$ was used as compared to $3 \mathrm{~kg}$ seed rate $\mathrm{ha}^{-1}$. The result is agreed with the findings of $[30,31]$. Grain yield enhanced by increasing seed rates in canola.

\section{Oil concentration in grains $(\%)$}

Nitrogen levels, seed rates as well as their combination $\mathrm{N}$ x SR differed significantly, oil concentration in canola crop as shown in (Table 2). Oil content is inversely affected by nitrogen application. Maximum oil content (45, 44 and $40 \%)$ were obtained with the application of nitrogen applied at 50 and 75 as compare to $100 \mathrm{~kg} \mathrm{~N} \mathrm{ha}^{-1}$ [32]. Among the application of seed rates, $6 \mathrm{~kg} \mathrm{ha}^{-1}$ gave maximum (45\%) oil as compared to all others treatments. Higher seed rate increased plant competition for nutrients and other environmental factors, while lower seed rate decreased plant competition and hence resulted in higher oil content \%. Similar result by [33]. In case of the interaction, maximum oil content was gained with the interactive treatments of $75 \mathrm{~kg}$ nitrogen and 3 $\mathrm{kg}$ seed rate ha ${ }^{-1}$ as shown in (Figure 3). 
Table 2. Represent data on thousand grains weight (g), grain yield ( $\left.\mathrm{kg} \mathrm{ha}^{-1}\right)$ and oil content (\%) of canola as impacted by different nitrogen levels and seed rates

\begin{tabular}{|c|c|c|c|}
\hline $\begin{array}{c}\text { Treatments } \\
\text { Nitrogen }\left(k g-h a^{-1}\right)\end{array}$ & $\begin{array}{c}1000 \text { grains } \\
\text { weight }(g)\end{array}$ & $\begin{array}{c}\text { Grain yield } \\
\left(\mathrm{kg} \mathrm{ha}^{-1}\right)\end{array}$ & Oil content $(\%)$ \\
\hline 0 & $3.1 \mathrm{~d}$ & $1518 \mathrm{~b}$ & $44 \mathrm{~b}$ \\
\hline 50 & $3.2 \mathrm{c}$ & $1679 b$ & $45 a$ \\
\hline 75 & $3.3 \mathrm{~b}$ & $2041 \mathrm{a}$ & $44 \mathrm{~b}$ \\
\hline 100 & $3.5 \mathrm{a}$ & $2211 \mathrm{a}$ & $40 \mathrm{c}$ \\
\hline LSD Value & 0.07 & 195.28 & 0.96 \\
\hline \multicolumn{4}{|l|}{ Seed rates $\left(\mathrm{kg} \mathrm{ha}^{-1}\right)$} \\
\hline 3 & $3.2 \mathrm{c}$ & $1688 b$ & $44 \mathrm{~b}$ \\
\hline 6 & $3.3 b$ & $1873 \mathrm{ab}$ & $45 \mathrm{a}$ \\
\hline 9 & $3.4 \mathrm{a}$ & $2026 a$ & $42 c$ \\
\hline LSD Value & 0.08 & 225.49 & $\mathbf{0 . 8 3}$ \\
\hline LSD Value for interaction & 0.14 & & 1.66 \\
\hline $\mathbf{S} \times \mathbf{N}$ & $* *$ & Ns & $* *$ \\
\hline
\end{tabular}

Means with letters differ-significantly according to-Least Significant Difference (LSD) test $(\mathrm{P}<0.05)$, ns stands for non-significant difference and* at $\mathrm{P}<0.05$ level, respectively

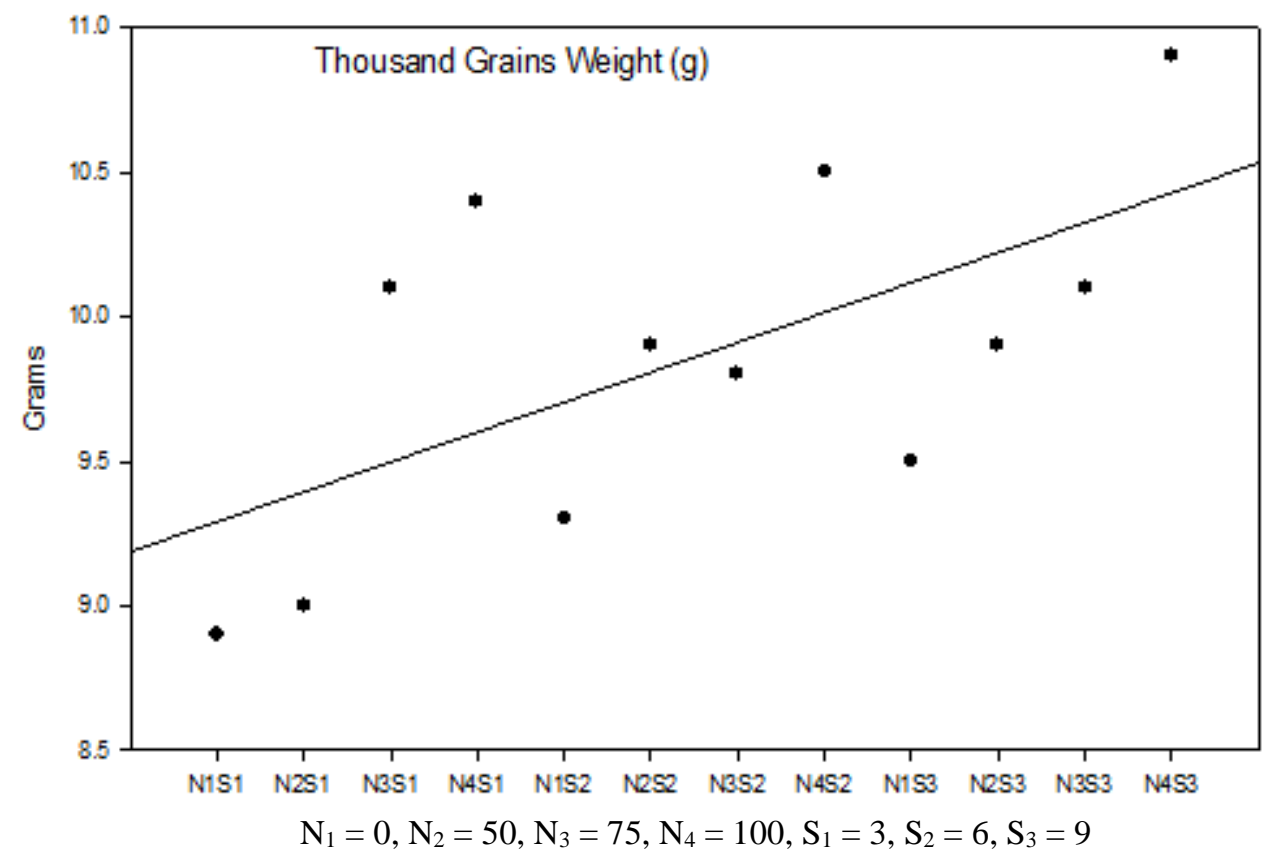

Figure 2. Thousand grains weight of canola as affected by interaction of different nitrogen levels and seed rates 


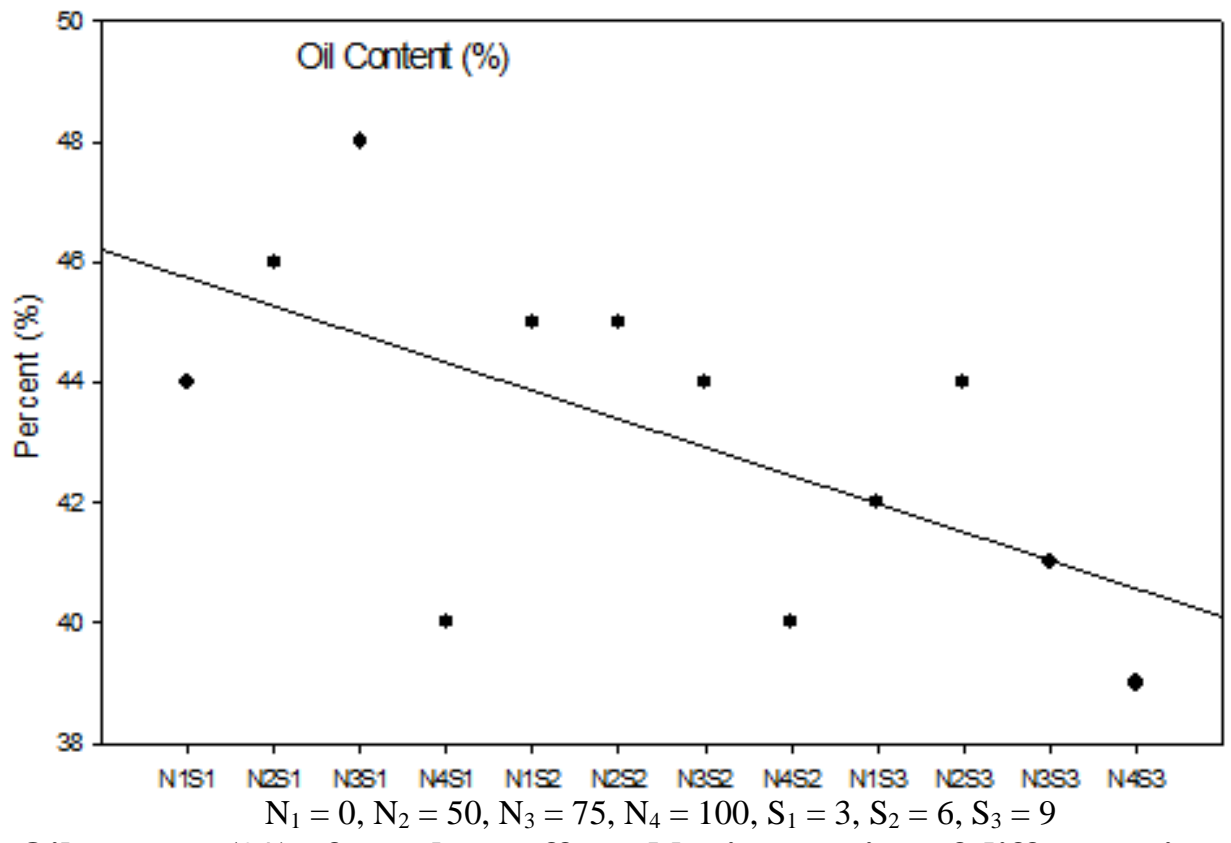

Figure 3. Oil content $(\%)$ of canola as affected by interaction of different nitrogen levels and seed rates

Absolute growth rate (AGR g m $\mathbf{~ m a y}^{-1}$ ) The application of nitrogen, seed rate and their combinations $\mathrm{N} \times \mathrm{SR}$ showed significant variation for absolute growth rate (AGR) as shown in (Table 3). Higher absolute growth rate (AGR) $\left(2.7 \mathrm{~g} \mathrm{~m}^{-2}\right.$ day $\left.^{-1}\right)$ was noted with the treatment of nitrogen@ $100 \mathrm{~kg} \mathrm{ha} \mathrm{ha}^{-1}$, while less mean value of absolute growth rate (AGR) (1.9 $\mathrm{g} \mathrm{m}^{-2}$ day $^{-1}$ ) were recorded in control plots. Among various seed rate, a greater mean value of absolute growth rate (AGR) $\left(2.6 \mathrm{~g} \mathrm{~m}^{-2}\right.$ day $\left.^{-1}\right)$ was noted in plots received seed rate @ $3 \mathrm{~kg}$ ha $^{-1}$ while $9 \mathrm{~kg} \mathrm{ha}^{-1}$ seed rate gave minimum absolute growth rate (AGR) $\left(2.0 \mathrm{~g} \mathrm{~m}^{-2} \mathrm{day}^{-1}\right)$. In case of interaction, maximum absolute growth rate (AGR) $\left(12.0 \mathrm{~g} \mathrm{~m}^{-2}\right.$-day $\left.{ }^{-1}\right)$ was observed with the sole application of seed rate $3 \mathrm{~kg}$ and nitrogen $100 \mathrm{~kg} \mathrm{ha}^{-1}$ as compared to all others possible combinations as reported in (Figure 4). The same finding was discussed by [34], that the application of nitrogen enhances the growth and the ratio of growth.

\section{Nitrogen content in grain $(\%)$}

Nitrogen, seed rate and their combinations $\mathrm{N}$ $x$ SR varied significantly nitrogen content in grains as shown in (Table 3). Maximum nitrogen content in grains $(2.7 \%)$ was observed with $100 \mathrm{~kg} \mathrm{~N} \mathrm{ha}^{-1}$ and minimum of (1.9 \%) was observed in control plots. Among various seed rate levels maximum $\mathrm{N}$ content in grains $(2.6 \%)$ was noted with $3 \mathrm{~kg}$ seed rate ha- ${ }^{-1}$, while $9 \mathrm{~kg}$ seed rate ha ${ }^{-1}$ gave minimum $(2.0 \%)$ nitrogen content in grains. In case of interactions, seed rate of $3 \mathrm{~kg}$ and nitrogen $100 \mathrm{~kg} \mathrm{ha}^{-1}$ was superior and produced $(2.9 \%)$ nitrogen content in grains as compared to all other combinations as presented in (Figure 4). The result is supported by the findings of [35].

\section{Nitrogen content in straw $(\%)$}

Nitrogen content $(\%)$ in straw was affected significantly with the application of nitrogen, seed rate and their combinations $\mathrm{N} \times \mathrm{SR}$ as shown in (Table 3). Maximum nitrogen content in canola straw $(1.6 \%)$ was noted when nitrogen was applied @ $100 \mathrm{~kg} \mathrm{ha}^{-1}$ and minimum $(0.7 \%)$ was observed in control plots. Regarding seed rates application, higher nitrogen content in straw $(1.5 \%)$ was noted with $3 \mathrm{~kg}$ seed rate ha ${ }^{-1}$ while $9 \mathrm{~kg}$ seed rate $\mathrm{ha}^{-1}$ gave minimum $(0.9 \%)$ of nitrogen content. In case of combination, a greater nitrogen content in straw $(1.8 \%)$ was recorded when nitrogen $100 \mathrm{~kg}$ and seed rate 
$3 \mathrm{~kg} \mathrm{ha}^{-1}$ was used as match with all other possible combinations as presented in (Figure 4) [35].

Table 3. Represent data on absolute growth rate (AGR), nitrogen content in canola grains and nitrogen content in canola straw as impacted by nitrogen levels and seed rates

\begin{tabular}{|c|c|c|c|}
\hline Treatments & \multirow{2}{*}{$\operatorname{AGR}(\%)$} & \multirow{2}{*}{$\mathrm{N}$ in Grains (\%) } & \multirow{2}{*}{$\mathrm{N}$ in straw $(\%)$} \\
\hline Nitrogen $\left(\mathrm{kg} \mathrm{ha}^{-1}\right)$ & & & \\
\hline 0 & $2.3 d$ & $1.9 \mathrm{~d}$ & $0.7 \mathrm{~d}$ \\
\hline 50 & $5.0 \mathrm{c}$ & $2.2 \mathrm{c}$ & $1.0 \mathrm{c}$ \\
\hline 75 & $8.3 \mathrm{~b}$ & $2.5 b$ & $1.4 \mathrm{~b}$ \\
\hline 100 & $10.3 \mathrm{a}$ & $2.7 \mathrm{a}$ & $1.6 \mathrm{a}$ \\
\hline LSD Value & $\mathbf{0 . 4 3}$ & 0.11 & 0.6 \\
\hline \multicolumn{4}{|l|}{ Seed rates $\left(\mathrm{kg} \mathrm{ha}^{-1}\right)$} \\
\hline 3 & $7.4 \mathrm{a}$ & $2.6 \mathrm{a}$ & $1.5 \mathrm{a}$ \\
\hline 6 & $6.4 \mathrm{~b}$ & $2.3 b$ & $1.1 \mathrm{~b}$ \\
\hline 9 & $5.5 \mathrm{c}$ & $2.0 \mathrm{c}$ & $0.9 \mathrm{c}$ \\
\hline LSD Value & 0.37 & 0.1 & 0.05 \\
\hline LSD Value for interaction & 0.75 & 0.20 & 0.11 \\
\hline $\mathbf{S} \times \mathbf{N}$ & $* *$ & $* *$ & $* *$ \\
\hline
\end{tabular}

Means with letters-differ significantly according-to Least Significant-Difference (LSD) test (P<0.05), ns stands-for non-significant difference and* at $\mathrm{P}<0.05$ level, respectively

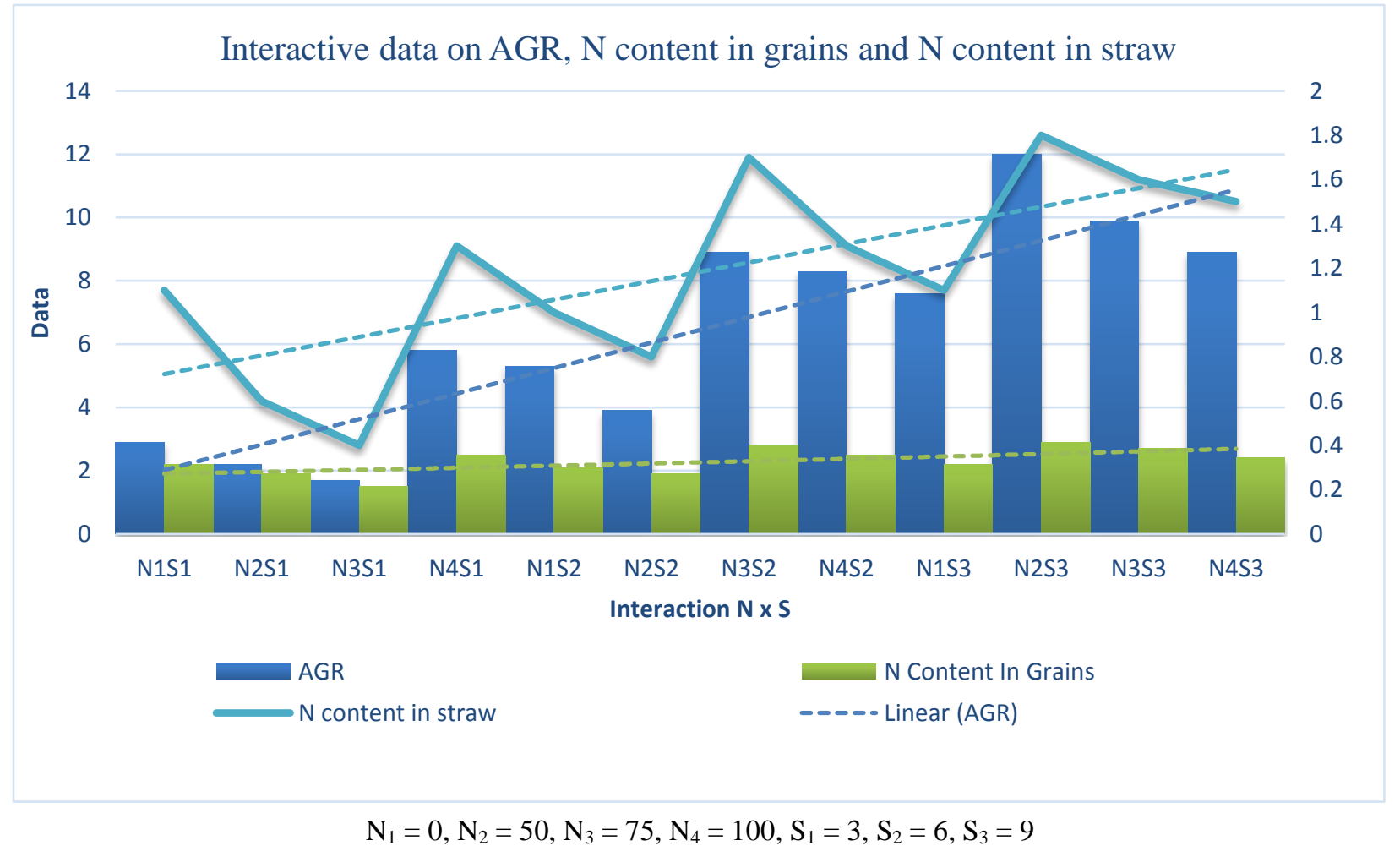

Figure 4. Absolute growth rate (AGR), nitrogen content in grains and nitrogen content in straw of canola as affected by interaction of different nitrogen levels and seed rates 


\section{Conclusion}

It's concluded from the results of the experiment that seed rate of $9 \mathrm{~kg} \mathrm{ha}^{-1}$ increased grain yield of canola while oil content (\%) could be increased with $6 \mathrm{~kg}$ seed rate $\mathrm{ha}^{-1}$. Nitrogen application at $100 \mathrm{~kg} \mathrm{ha}^{-1}$ enhanced grain yield and could be recommended for maximum grain yield but nitrogen applied at $50 \mathrm{~kg} \mathrm{ha}^{-1}$ produced maximum oil content (\%) in canola and could be recommended for obtaining higher oil content (\%).

\section{Authors' contributions}

Conceived and designed the experiments: SN Khan \& Z Hussain, Performed the experiments: SN Khan, Z Hussain, WA Shah \& R Amin, Analyzed the data: M Ishaq, A Khan, M Ahmad \& S Uddin, Contributed materials/ analysis/ tools: M Wisal, S Allah $\&$ M Ali, Wrote the paper: M Ishaq.

\section{References}

1. Muhammad J, Islam M, Khan B, Anjum, Hussain Z, Shah WA, Amin R, Ali J, Ishaq M \& Rehman AU (2017). Growth and yield attributes of canola varieties under different seed rates. Pure and App Bio 6(3): 864-870.

2. Syed AH, Jan A, Akbar H, Ali A, Khan KW, Rehan, W, Rahman AU \& Khan K (2018). Response of canola to row configuration, humic acid and Sulphur application. Pure and App Bio (8)1: 256-270.

3. Shafiullah, Munsif F, Ali A, Alam JE, Khan S, Kakar HA, Fahad S \& Jalal R (2018). Effect of nitrogen and sulfur on weed infestation and rapeseed productivity. Pure and App Bio 7(1): 321-329.

4. Khan B, Jawad M, Ahmad M, Islam M, Anjum, Yar M, Ilyas M, Kakar HA, Khan SN \& Fahad S (2018). Effect of seed rates on yield and oil components of canola genotypes. Pure and Appl Bio (7)2: 500-508.

5. Kumar A, Singh DP, Bikram S \& Yashpal $Y$ (2001). Effects of nitrogen application and partitioning of biomass, seed yield and harvest index in contrasting genotype of oilseed brassica. Ind J Agro 46: 528-532.
6. Laaniste P, Jaudu J \& Eremeev V (2004). Oil content of spring oilseed rapeseeds according to fertilization. Agro Res 2: 83-86.

7. Chamorro AM, Tamagno LN, Bezus R \& Sarandon SJ (2002). Nitrogen accumulation, partition and nitrogen-use efficiency in canola under different nitrogen availabilities. Commun. Soil Sci Plant Anal 33: 493-504.

8. Fathi G, Saeidi AB, Siadat SA \& Ebrahimpour F (2002). Effect of different levels of nitrogen fertilizer and plant density on seed yield of Colza cv. PF 7045 under Khuzestan province conditions. Sci J Agr Ahwaz (Iran) 25: 43-58.

9. Leach J, Stevensen H \& Renbow AJ (1998). Effect of high plant population on growth and yield of winter rapeseed oil. J Agr Sci Cambridge 132: 173-180.

10. Prasad S \& Shakla DN (1991). The effect of nitrogen and plant population on yield, percent of oil seed of canola. Can J Plant Sci 38: 283- 291.

11. Walch-Liu P, Neumann G, Bangerth F \& Engels C (2000). Rapid effects of nitrogen form on leaf morphogenesis in tobacco. $J$ of Expe Bot 51:227-23

12. Fathi G, Saeidi AB, Siadat SA \& Ebrahimpour F (2002). Effect of different levels of nitrogen fertilizer and plant density on seed yield of Colza cv. PF 7045 under Khuzestan province conditions. Sci J Agr Ahwaz(Iran) 25: 43-58.

13. Cheema MA, Saleem MF, Muhammad N, Wahidi MA \& Baber BH (2010). Impact of rate and timing of nitrogen application on yield and quality of canola. Pak J Bot 42(3): 1723-1731.

14. Hocking PJ \& Stapper M (2001). Effect of sowing time and nitrogen fertilizer on canola and wheat and nitrogen fertilizer on Indian mustard in dry matter production, grain yield and yield components. Aus J of Agri Res 52: 623-634.

15. Mendham NJ, Naraki M \& Salisbury PA (1995). Physiology: Crop development, growth and yield. Brassica oilseeds: production and utilization. (Eds.) DS Kimber \& McGregor DI 11-64 Wallingford: CAB. 
16. Leach JE, Stevenson AH, Rainbow AJ \& Mullen LA (1999). Effects of high plant populations on the growth and yield of winter oilseed rape (Brassica napus L.). J of Agri Sci 132: 173-180

17. Morrison MJ, McVetty PBE \& Scarth $R$ (1990). Effect of row spacing and seeding rates on summer rapeseed in southern Manitoba. Can J Plant Sci 70: 127-137

18. Angadi SVHW, Cutforth BG, McConkey \& Gan Y, (2003). Yield adjustment by Canola grown at different plant populations under semiarid conditions. Crop Sci 43: 13581366.

19. Ali Y, Ahsan MH, Tahir GR \& Ahmad N (1999). Effect of Inter and Intra Row Spacing on the Yield and Yield Components of Chickpea. Pak J Bio Sci 2(2): 305-307.

20. Chen CG, Jackson G, Neill KD (2005). Determining the feasibility of early seeding canola in the northern Great Plains. Agro J 97: 1252-1262.

21. Diepenbrock, W (2000). Yield analysis of winter oilseed rape (Brassica napus L.): a review. Field Crops Research 67(1): 35-49.

22. Brandt SAM, Ulrich D, Lafond GP, Kutcher HR \& Johnston AM (2007). Seeding rate, fertilizer level and disease management effects on hybrid versus open pollinated canola (Brassica napus L.). Can J Plant Sci 87: 255-266.

23. Malhi S \& Gill KS (2004). Placement, rate and source of $\mathrm{N}$, seed row opener and seeding depth effects on canola production. Can J Plant Sci 84: 719-729

24. Kutcher HR, Malhi SS \& Gill KS (2005). Topography and management of nitrogen and fungicide affects diseases and productivity of canola. Agron J 97: 533-541.

25. Clayton GW, Harker KN, Johnston A M \& Turkington KT (1999). Response of hybrid canola to seeding rate, fertility and time of weed removal. In "In New Horizons for an old crop" Proceedings of the 10th International Rapeseed Congress.

26. Al-Jaloud AAG, Hussian S, Karimulla \& AlHamidi AH (1996). Effect of irrigation and nitrogen on yield and yield components of two rapeseed cultivars. Agric Water Manag 30: $57-68$.

27. Karamzadeh A, Mobasser HR, Ramee V \& Ghanbari MA (2010). Effects of Nitrogen and seed rates on yield and oil content of canola (Brassica napus L.). Ame Eura J Agric \& Envi Sci 8(6): 715-721.

28. Malhi SS \& KS, Gill (2006). Cultivar and fertilizer srate interaction effect on canola yield, seed quality and s uptake. Can $J$ plant Sci 86: 91-98

29. Arslan N, 1994. Effect of sowing date and plant density on seed yield of Nigel (Nigella damascene L). J Field Crops Cent Res Inst 3: $1-2$

30. Thurling N (1974). Morphophysiological determinants of yield in rapeseed (Brassica campestris and Brassica napus). Aust $J$ Agric Res 25: 711-721.

31. Ogrodowczyk M \& Wawrzyniak M (2004). Adoption and path-coefficient analysis for assessment of relationship and interrelationship of yield and yield parameters of winter oilseed rape. Rosliny Oleiste 25(2): 479-491.

32. Al-Barrak KM (2006). Irrigation interval and nitrogen level effects on growth and yield of canola (Brassica napus L.). Sci J of King Faisal University 7(1): 87-103.

33. Vanda SF, Aynehband A \& Naraki F (2009). Effects of tillage method, seed rate and microelement spraying time on seed yield and yield components of rapeseed in warm dryland condition. J Food Agric \& Envi 7(34): 627-633.

34. Mumtaz A, Cheema, Sattar A, Wahid MA, Saleem MF \& Sadiq S (2012). Growth, yield and quality response of various canola cultivars under agro-ecological condition of Faisalabad. Pak J Agri Sci 49(1) 35-39.

35. Malidarreh AG (2010). Effects of Nitrogen Rates and Splitting on Oil Content and Seed Yield of Canola (Brassica napus L.). Ameri Eurasian J Agric \& Envi Sci 8(2): 161-166. 